\title{
Hiv-blivandets känslolandskap
}

\author{
Ljungcrantz, Desireé Skrubbsår: En berättelse om hur hiv föreställs och \\ erfars i samtida Sverige (diss.). Makadam 2017 (240 sidor)
}

DESIREÉ LJUNGCRANTZ AVHANDLING Skrubbsår: En berättelse om hur hiv föreställs och erfars $i$ samtida Sverige (2017), framlagd vid Tema Genus vid Linköpings universitet, är som så mycket annan av dagens genusvetenskapliga forskning intersektionellt inriktad. Sara Ahmed, Judith Butler och inte minst Ljungcrantz huvudhandledare Nina Lykke är frekventa referenser i såväl inledningskapitlet som i den löpande analysen. Lika närvarande $\mathrm{i}$ texten är ett fenomenologiskt perspektiv på hälsa och sjukdom: upplevelser, erfarenhet, mening och kroppslighet är exempelvis några teman som studeras i relation till hiv. Studien använder sig av traditionella samhälls- och kulturvetenskapliga metoder - som intervjuer och närläsningar av "populärkulturella berättelser" (Ljungcrantz 20I7, 3I) i form av två självbiografier och två dokumentärfilmer men också av vad som skulle kunna beskrivas som autoetnografi: genom att systematiskt undersöka forskarens egna upplevelser och erfarenheter som en del av avhandlingens empiri vill studien närma sig en fördjupad förståelse av hiv. Ljungcrantz använder själv begreppen autofenomenografi och autofiktion, en typ av metod och gestaltning som används för att, som hon formulerar det, "förmedla mina resultat, att skriva nära hiv, samtidigt som det belyser kunskapers situerade tillblivelse" (20).

Det vetenskapliga hantverket bakom intervjuerna beskrivs klart och tydligt. Ljungcrantz har valt att göra idealtyper, "fiktiva personer" eller "karaktärer" (36) baserade på intervjuerna, ett persongalleri som 
återkommer genom avhandlingens olika kapitel. De citat som används i texten är dock exakt återgivna betonar Ljungcrantz, direkt hämtade från de tolv intervjuer som utgör intervjumaterialets samlade empiri. Greppet innebär givetvis en form av anonymisering. Jag uppfattar dock att huvudorsaken är analytisk och metodologisk, ett val som görs för att skriva fram en gemensam arena där olika materialtyper kan mötas, analyseras och relateras till varandra. För en annan viktig del av avhandlingens material är "de autofiktiva Desideriaberättelserna" (35), det vill säga de litterära eller poetiska texter som beskriver författarens alter ego Desideria - "en textuell kropp" (20) - som inramar och empiriskt starkt genomsyrar hela avhandlingen. De litterära textpartierna avser alltså att uttrycka och gestalta olika känslor hos författaren men också finna en distans till dessa, en spänning mellan närhet och avstånd som så att säga skrivs fram av både existentiella och analytiska skäl. "Det är i det kreativa skrivandets flöden, dess skiftande rytm, i ordlekar och bilder jag skriver nära hiv" (53), sammanfattar Ljungcrantz sitt tillvägagångssätt för hur den egna erfarenheten i litterär form kan läggas till grund för en vetenskaplig undersökning.

Och det är just närheten till hiv, till diagnosen och dess effekter om man så vill, som är avhandlingens grundläggande utgångspunkt. Ett första syfte blir därför att undersöka det "relationella hiv-blivandet" (30) som Ljungcrantz formulerar det, om hur hiv blir till och samskapas av individer och institutioner samt hur hiv som ett kroniskt sjukdomsfenomen erfars och framställs i en samtida nationell kontext. Individens vardagsliv hamnar här i centrum men också offentliga berättelser om hiv där individuella erfarenheter omgestaltas till en kollektiv och publik nivå. Det andra syftet uppfattar jag som mer metodologiskt, ett slags utforskande av den autofiktiva metodens analytiska räckvidd genom exemplet hiv. Studien fokuserar här på hur ett "poetiskt skrivande" kan generera "analyser, teman och forskningsreflektioner", hur ett skönlitterärt inspirerat gestaltade kan "forma och formulera kunskaper på kännbara, icke-distanserade sätt" (32).

Ljungcrantz avhandling lägger sig uppenbart nära den ambition att beforska känslor som ibland betecknas som den "affektiva vändningen". 
Kortfattat innebär detta en ökad uppmärksamhet på vilken betydelse känsloliv och kroppslighet har för vårt sätt att förstå oss själva och vår omvärld, för hur känslor och samhällsstruktur ömsesidigt formar - och omformar - varandra. Historiker har dock länge utforskat framför allt svunna tiders känslovärldar - Johan Huizinga och Norbert Eilas brukar lyftas fram som pionjärer - men också företrädare för den klassiska svenska kvinnohistoriska forskningen som Karin Westman Berg visade tidigt på de egna upplevelsernas värde i vetenskapliga sammanhang, Westman Berg ofta förknippad med slagordet "Gråt inte - Forska!" efter namnet på en antologi från 1979. Engagemanget - såväl de emotionella som det politiska - är tydligt även i Ljungcrantz text. "Ambitionen", skriver hon uttryckligen, "är att min studie i någon mån kan inspirera till förändring och nyansering av samhällets syn på hiv" (30).

Hur utfaller då Ljungcrantz analys av vår tids föreställningar om hiv och hur hiv erfars av personer med hiv - spårbara genom samtal med informanter, i populärkultur och genom den individuella röstens erfarenheter? Och vilka nyanser av att hur det är att leva med hiv i dag är det som presenteras, vilka mönster framträder och hur analyseras dessa i avhandlingstexten?

En styrka i avhandlingen är det fenomenologiska perspektivet, i texten presenterad som en analys som fokuserar på "orienteringar, kroppslighet och känslomässiga dimensioner i de levda erfarenheterna" (62). Avhandlingens huvudmaterial är här intervjuerna men också de så kallade "Desideriaberättelserna", det vill säga de textpartier som baseras i författarens egna erfarenheter - om än återberättade och sammanställda i en mer litterär form. Såväl citaten som de inspränga partier där författarens framskrivna karaktär Desideria kommer till tals ger avhandlingstexten en stark närhet, en påtaglig innanför-skinnet-presentation som visar på metodvalets styrka. Analysen av det populärkulturella materialet utförs på ett liknande sätt, det vill säga med ambitionen att genom berättelserna närma sig hur hiv kan kännas men också förklaras och förstås i relation till samtida maktordningar.

En av avhandlingens viktigaste slutsatser är att en hiv-diagnos - trots att många av de intervjuade inledningsvis ofta uttrycker att hiv inte 
är en så stor sak - ännu i dag kan ha ett mycket stor inflytande på enskilda människors liv. Hiv drar alltså individen åt olika håll, påverkar såväl relationer och livsval som självbild och identitet. Tankar kring exempelvis virusets medicinska dimensioner, inte minst oron för att föra viruset vidare men också de existentiella och juridiska följderna av en allt effektivare behandling som i princip kan sänka virusnivån under mätbarhetens gräns, gestaltas tydligt genom Ljungcrantz täta beskrivningar av hur hiv utspelas - eller levs och erfars - i människors vardag. Avhandling visar alltså att hiv fortfarande, lite slarvigt uttryckt, inte är en diagnos bland andra.

DAVID THORSÉN STOCKHOLMS UNIVERSITET 